\title{
Todo tiempo pasado
}

All past time

\section{ZOE GARCÍA MiRANDA}

Licenciada en Medios de Comunicación Audiovisual en la especialidad de Fotografía en el Instituto Superior de Arte de la Habana. En el 2008 pasó a estudiar Cine Documental en la Escuela Internacional de Cine y TV de San Antonio de los Baños. Ha dirigido los documentales No te puedo llamar, Retrato y ElMundo de Raúl.

\section{CORTOMETRAJE DOCUMENTAL}

SINOPSIS: Usando como punto de partida el célebre restaurante Moscú, destruido por un incendio a principio de los anos 90, Todo tiempo pasado dialoga sobre las influencias del legado soviético en la Cuba actual. 2008, (32 minutos).

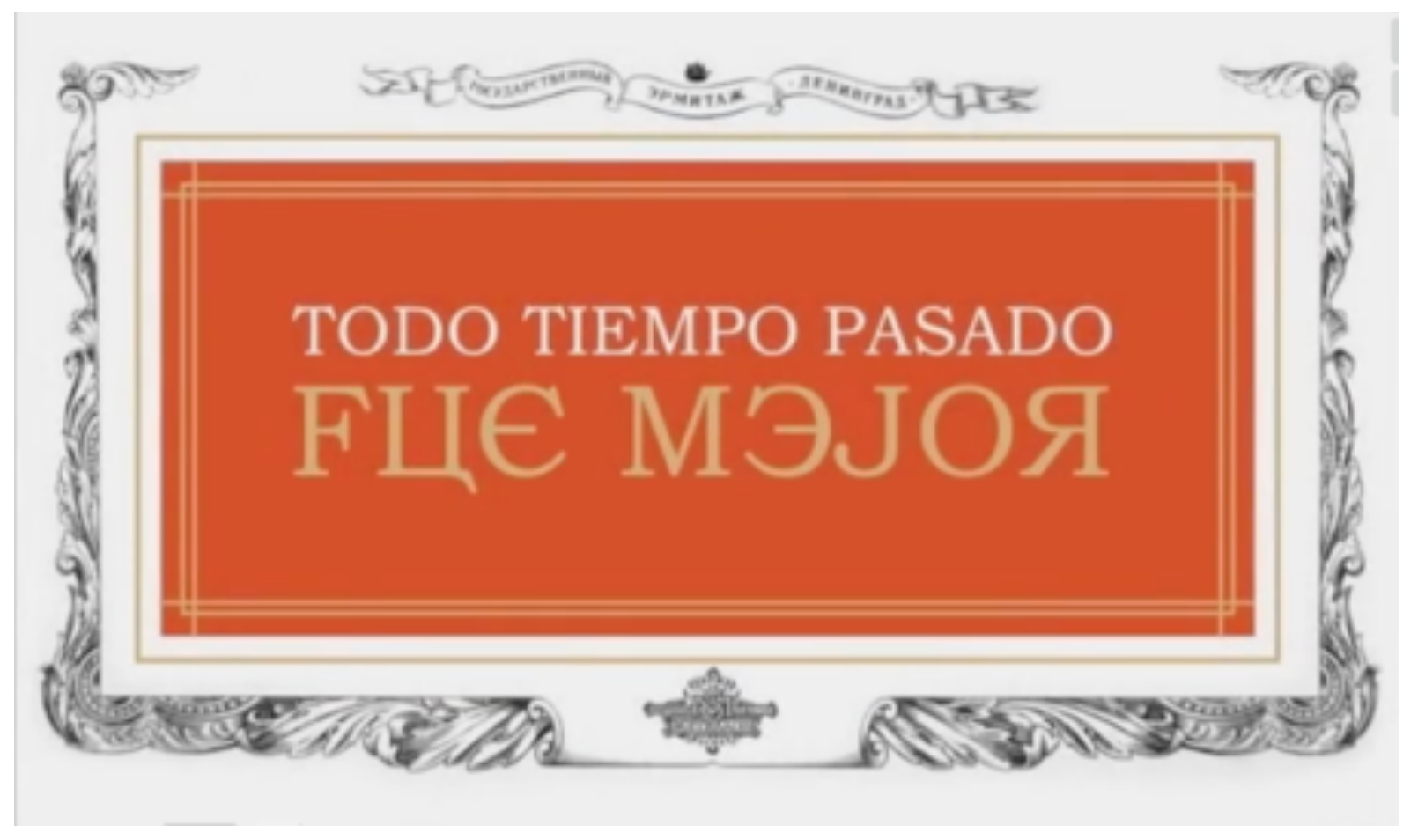

Ver Todo tiempo pasado.

DOI: 10.7203/KAM.5.6806 
"Todo tiempo pasado es una exploración extensa del legado de los tiempos de la presencia soviética en Cuba. Su larga lista de entrevistados abordan desde múltiples experiencias de vida, saberes científicos o artísticos y estimaciones del valor probable de la experiencia histórica, el período. Todo ello, ahuecando las declaraciones de autoridad con breves intervenciones de gente anónima. (...) Todo tiempo pasado incluye el acto del recordar como experiencia de la memoria de delicadas resonancias para una sociedad como la cubana, cuyas generaciones mayores de veinte años suelen referir los tiempos anteriores a la desaparición del socialismo europeo y la URSS como tiempo dichoso. La evocación suele transformarse entonces en un acto performativo díscolo, sinestésico, que irremediablemente acaba haciendo presentes eventos y circunstancias del pasado. El acto de recordar rebasa los marcos testimoniales y adquiere el significado de un lamento generalizable al entorno social de una época y sociedad.

\section{$(\ldots)$}

Todo tiempo pasado se enhebra a partir de la ruina del célebre restaurante habanero Moscú, destruido en un incendio en torno a la misma época en que se derrumbaba el universo mítico en que estaba inspirado. Los realizadores del documental aprovechan el marco alegórico que tantas coincidencias pohíjan para explorar el prontuario de desapariciones que sufrió el mapa referencial cubano".

Dean Luis Reyes

Gaceta de Cuba 1 (2010): 7 